\title{
Pancreatic cancer cells isolated from Muc1-null tumors favor the generation of a mature less suppressive MDSC population
}

\section{Amritha Kidiyoor, Jorge Schettini ${ }^{+}$, Dahlia Marie Besmer ${ }^{\dagger}$, Stephen Lee Rego, Sritama Nath, Jennifer Marie Curry, Lopamudra Das Roy, Didier Dréau and Pinku Mukherjee*}

Department of Biology, University of North Carolina at Charlotte, Charlotte, NC, USA

\section{Edited by:}

Bibhash Mukhopadhyay, Johnson \&

Johnson, USA

Reviewed by:

Graham Robert Leggatt, University of Queensland, Australia

Jürgen Krauss, National Center for

Tumor Diseases, Germany

${ }^{*}$ Correspondence:

Pinku Mukherjee, Department of Biology, University of North Carolina at Charlotte, Woodward Room $490 \mathrm{C}$ 9201 University City Blvd, Charlotte, NC 28223, USA

e-mail:pmukherj@uncc.edu

${ }^{\dagger}$ Jorge Schettini and Dahlia Marie Besmer have contributed equally to this work.
Mucin 1 (MUC1) is a transmembrane mucin glycoprotein that is over-expressed and aberrantly glycosylated in $>80 \%$ of human pancreatic ductal adenocarcinoma (PDA) and is associated with poor prognosis. To understand the role of MUC1 in PDA, we have recently developed two mouse models of spontaneous PDA, one that expresses full-length human MUC1 transgene (KCM mice) and one that is null for MUC1 (KCKO mice). We have previously reported that $\mathrm{KCM}$ mice express high levels of myeloid derived suppressor cells (MDSCs) in their tumors and develop highly aggressive PDA. To further understand the underlying mechanism for high MDSC levels in KCM-tumors, we generated primary cell lines from KCM and KCKO-tumors. In this study, we report that MDSCs derived using KCM cells express significantly higher levels of arginase 1 and inducible nitric oxide synthase (markers associated with immune suppression) and lower levels of CD115 (a marker associated with maturation of myeloid cells) as compared to KCKO-derived MDSCs. Functionally, KCM-derived MDSCs secrete significantly higher levels of urea and nitric oxide (NO) when co-cultured with normal splenic cells as compared to KCKO-derived MDSCs. Data indicates that KCM-derived MDSCs remain immature and are more suppressive as compared to KCKO-derived MDSCs. This was further corroborated in vivo where MDSCs isolated from KCM-tumor-bearing mice retained their immature state and were highly suppressive as compared to MDSCs derived from KCKO-tumor-bearing mice. Finally, we show that KCM cells secrete significantly higher levels of prostaglandin E2 (PGE 2 ), a COX-2 metabolite and a known driver of suppressive MDSCs as compared to KCKO cells. Thus, inhibiting PGE 2 with a specific COX-2 inhibitor reverses the immunosuppressive and immature phenotype of KCM-derived MDSCs. This is the first report that clearly suggests a functional role of pancreatic tumor-associated MUC1 in the development of functional MDSCs.

\section{INTRODUCTION}

Every year, an estimated 270,000 deaths occur worldwide due to pancreatic cancer (1), and in the US, the 1- and 5-year survival rates for all stages combined are 25 and $6 \%$, respectively (2). Therapies that are successful in treating other malignancies are relatively ineffective for pancreatic cancer possibly because cells evade immune recognition (3). Cancer cells release pro-inflammatory factors that promote the generation of immune suppressor cells including myeloid derived suppressor cells (MDSCs) (3). MDSCs play a prominent role in tumor induced immune suppression and are one of the major factors limiting the efficacy of immune therapies $(4,5)$.

Abbreviations: Arg-1, arginase 1; BM, bone marrow; BMDCs, bone marrow derived cells; COX-2, cyclooxygenase 2; iNOS, inducible nitric oxide synthase; KCKO, PDA cell line without MUC1; KCM, PDA cell line expressing MUC1; MDSCs, myeloid derived suppressor cells; MUC1 (human) Muc1 (murine), Mucin 1; NO, nitric oxide; PDA, pancreatic ductal adenocarcinomas; PGE2, prostaglandin E2; TCCM, tumor cell conditioned media; TDSFs, tumor derived soluble factors.
Pancreatic ductal adenocarcinoma (PDA) is the most common type of pancreatic cancer. MUC1 (CD227), a transmembrane mucin glycoprotein is aberrantly over-expressed in $>80 \%$ of PDA. This suggests a pivotal role for MUC1 in the progression of PDA. MUC1 plays a role in inflammation (6) and cancer progression (7) and has recently been identified as the second most targetable tumor-associated antigen by the National Cancer Institute (8). Indeed, $64 \%$ of the tumors diagnosed every year in the United States have aberrant MUC1 expression (7). MUC1 regulates multiple pro-tumor activities including proliferation (9), epithelial to mesenchymal transition (10), and inhibition of apoptosis (11) in tumor cells. However, its role in tumor induced immune suppression and specifically in the generation of MDSCs is not well known.

We were the first to report that in a mouse model of spontaneous PDA (12), overexpression of human MUC1 transgene (PDA.MUC1 mice) significantly enhanced tumor progression and metastasis and showed increased levels of MDSCs and T-regulatory cells $\left(\mathrm{T}_{\text {regs }}\right)$ as well as prostaglandin $\mathrm{E}_{2}\left(\mathrm{PGE}_{2}\right)$ 
within the developing tumor (13). In contrast, PDA mice that lacked Muc1 (PDA.Muc1-null mice) had stable disease and the pre-neoplastic lesions did not progress to invasive adenocarcinomas $(9,10)$. The findings strongly suggest a role for MUC1 in tumor induced immune suppression; possibly via the generation of suppressive MDSCs.

Myeloid derived suppressor cells consist of a heterogeneous population of immature myeloid cell types (14). Generally, these immature myeloid cells differentiate further into mature granulocytes, macrophages, and dendritic cells. However, in cancer, inflammation, trauma, or sepsis, this differentiation process is halted and the myeloid cells remain restricted to their immature state (15). Specifically, tumor derived soluble factors (TDSFs) secreted by tumor cells alter MDSC generation, differentiation, recruitment, and function. TDSFs skew the differentiation of hematopoietic stem cells (HSC) partially hindering maturation of the myeloid lineage (15). In these conditions, MDSCs are found to accumulate in the BM, spleen, blood, lymph nodes, and within tumors $(16,17)$. TDSFs including PGE 2 (18, 19), GMCSF (20), and IL-10 (21) have been implicated in the induction of MDSCs. These factors not only lead to MDSC expansion but also MDSC activation. In addition, MDSCs can be activated by activated T-cells through the action of activated T-cell products; IFN $\gamma$, TGF- $\beta$, IL- 4 , and IL-13. In mice, MDSCs are characterized by the co-expression of Gr1 and CD11b molecules (22) and can be classified into subsets: monocytic (CD11b ${ }^{+}$Ly6G $^{-}$Ly6C $^{\text {hi }}$ ) and granulocytic $\left(\mathrm{CD}_{11 \mathrm{~b}}{ }^{+} \mathrm{Ly}_{6 \mathrm{G}^{+}} \mathrm{Ly}^{\mathrm{C}} \mathrm{C}^{\mathrm{lo}}\right)(23,24)$. MDSCs exert their suppressive activity via a number of different mechanisms; L-arginine depletion (25), nitric oxide (NO) up regulation (26), generation of reactive oxygen species (ROS) (24), and other free radicals including reactive nitric oxide species (RNOS) (27). These mechanisms suppress T-cell proliferation and T-cell effector function, thereby inhibiting anti-tumor immune responses.

In the present study, we compared the effects of TDSFs from PDA cells derived from PDA.Muc1-null mice (KCKO) with PDA cells derived from PDA.MUC1 (KCM) on MDSC phenotype and function in vitro and in vivo. We report substantive differences in the maturation state and suppressive function of the MDSCs derived in the presence of KCM versus KCKO cells/tumors. We also determined that KCM cells expressed significantly higher levels of COX-2 and secreted higher amounts of $\mathrm{PGE}_{2}$ as compared to KCKO cells. Thus, MDSC maturation and function may partly depend upon whether the PDA is $\mathrm{Mucl}^{+}$or Mucl-null.

\section{MATERIALS AND METHODS \\ CELL LINES AND MICE}

The KCKO pancreatic cancer cell line was generated from PDA.Muc1-null tumors and the KCM pancreatic cancer cell line was generated from PDA.MUC1 tumors (9). The murine fibroblast cell lines 3T12 and L929 (ATCC, Manassas, VA, USA), served as negative controls and B16 murine melanoma cell line (a gift from Dr. Tony Hollingsworth, University of Nebraska Medical Center) served as the positive control for $\mathrm{Gr}^{+}{ }^{+} \mathrm{CD} 11 \mathrm{~b}^{+}$ MDSCs. B16.Neo (transfected with neomycin empty vector) and B16.MUC1 (expressing full-length human MUC1) murine melanoma cells (a gift from Dr. Tony Hollingsworth, University of
Nebraska Medical Center), served as alternative MUC1 expressing and MUC1-null cells. All cell lines were maintained in DMEM (Invitrogen, Grand Island, NY, USA) supplemented with 10\% FBS (HyClone, Logan, UT, USA) and 1\% $1 \times$ penicillin/streptomycin (PS; Cellgro, Manassas, VA, USA). All cultures were kept at $37^{\circ} \mathrm{C}$ in a $5 \% \mathrm{CO}_{2}$ humidified atmosphere.

Mice (6- to 8-week-old C57BL/6, Jackson Laboratory, Bar Harbor, Maine, USA) were used for harvesting bone marrows (BM) and spleens and for generation of pancreatic tumors in vivo. Mice were handled and maintained in accordance with the University of North Carolina at Charlotte Institutional Animal Care and Use Committee (IACUC)-approved protocol.

\section{GENERATION OF CONDITIONED MEDIA}

Tumor cells were cultured with DMEM supplemented with reduced serum ( $2 \% \mathrm{FBS})$. Forty-eight hours post-incubation, the tumor cell conditioned media (TCCM) containing the TDSFs released by tumor cells were collected. The TCCMs were centrifuged $(3000 \mathrm{rpm}, 10 \mathrm{~min})$, filtered $(0.2 \mu \mathrm{m}$ filter, Fisher Scientific, Pittsburgh, PA, USA), and stored at $-80^{\circ} \mathrm{C}$ until use. Fibroblast conditioned media (FCMs) were obtained from $3 \mathrm{~T} 12$ and L929 fibroblast cells in a similar fashion.

\section{CELECOXIB TREATMENT}

KCM cells at $70 \%$ confluency were treated with the COX-2 inhibitor Celecoxib (50 $\mu \mathrm{M}$; Pfizer, New York City, NY, USA) in serum-free DMEM for $48 \mathrm{~h}$. Cells were washed twice with $1 \times \mathrm{PBS}$ and incubated for an additional $48 \mathrm{~h}$ with fresh DMEM supplemented with $2 \%$ FBS (reduced serum). TCCMs were collected, and stored as described above.

\section{PANCREATIC TUMOR GROWTH IN VIVO}

$1 \times 10^{6}$ cells of 3T12, B16.Neo and B16.MUC1, KCKO, and KCM cells were re-suspended in $100 \mu \mathrm{L}$ of $1 \times$ PBS:Matrigel ${ }^{\circledR}$ (BD Biosciences, San Jose, CA, USA) 1:1 and injected subcutaneously into the flank of C57BL/6 mice. Seventeen days post-injection, the mice were sacrificed and the tumor and organs harvested. The tumors were weighed and tumor lysates were prepared. BM and splenocytes were harvested and used as described below.

\section{GENERATION OF BONE MARROW PROGENITORS}

Bone marrow cells were obtained from the femurs and tibias of 6- to 8-week-old C57BL/6 mice. BM cells $\left(1 \times 10^{6}\right)$ were cultured in DMEM supplemented with $10 \%$ FBS, $1 \%$ PS, $10 \mathrm{ng} / \mathrm{ml} \mathrm{GM-}$ CSF (Peprotech, Rocky Hill, NJ, USA), 10 ng/ml IL-4 (Peprotech, Rocky Hill, NJ, USA), and $50 \mu \mathrm{M}$ of $2-\mathrm{ME}$ alone or in the presence of $30 \% \mathrm{v} / \mathrm{v}$ TCCM or control (FCM) in 24-well flat bottom plates as described in Ref. $(24,28,29)$. Cells were maintained at $37^{\circ} \mathrm{C}$ in $5 \% \mathrm{CO}_{2}$ humidified atmosphere for 5 days. On day 3 of culture, floating cells were removed and media replenished with GM-CSF, IL-4, and TCCM/FCM. As BM cultures are considered suppressive by day 5 (28), cells were collected on day 5 and analyzed by flow cytometry. The optimal TCCM concentration $(30 \% \mathrm{v} / \mathrm{v})$ was determined from titration curves of $\mathrm{Gr}^{+}{ }^{+} \mathrm{CD} 11 \mathrm{~b}^{+} \mathrm{MDSCs}$, this concentration was not associated with any noticeable BM cell death. To account for differing proliferation rates between cells and treatment conditions, BCA analyses were conducted on both 
cell lysates and conditioned media. The total protein concentrations were similar in the lysates and conditioned media obtained from KCKO, KCM, and KCM cells treated with Celecoxib (data not shown).

\section{FLOW CYTOMETRY}

Floating bone marrow derived cells (BMDC) and loosely adherent cells from BM cultures were collected, centrifuged, and cell pellet re-suspended in staining buffer (SB; $1 \times$ PBS with 1\% FBS and $0.1 \%$ sodium azide). Cells were stained with anti-Gr1-APC, antiCD11b-PE, anti-Ly6C-FITC, anti-Ly6G-APC, anti-CD11c-FITC, and biotinylated anti-CD115 for total MDSC population, subsets, and maturation phenotypes, respectively. For the detection of intracellular antigens, the cells were fixed and simultaneously permeabilized with BD Cytofix/Cytoperm and stained with antiiNOS-FITC and anti-Arg-1 primary antibody and appropriate secondary APC conjugated antibody. Splenocytes were harvested from spleens of 6- to 8-week-old C57BL/6 mice under sterile conditions, red blood cells were lysed $(1 \times \mathrm{RBC}$ lysing buffer $)$ and single-cell suspensions were prepared for staining with anti-Gr1APC and anti-CD11b-PE antibodies. KCM and KCKO cells were made into single-cell suspensions and stained with anti-MUC1$\mathrm{PE}$ antibody. All antibodies were purchased from BD Biosciences (BD Biosciences, San Jose, CA, USA). Samples were run on a FACSCalibur flow cytometer (BD Biosciences, San Jose, CA, USA) and data analyzed using the FlowJo software (Tree Star Inc., Ashland, OR, USA). Data are expressed as percentage positive cells and/or mean fluorescence intensity (MFI).

\section{BMDCs COLLECTED FOR NITRIC OXIDE AND ARGINASE ACTIVITY ASSAYS}

Bone marrow derived cells were generated as described above with the following modifications. On day 3, $100 \mathrm{U} / \mathrm{ml}$ IFN- $\gamma$ (Peprotech, Rocky Hill, NJ, USA) and 0.1-1 $\mu \mathrm{g} / \mathrm{ml}$ LPS (Sigma, St Louis, MO, USA) were added to enhance the suppressive activity of MDSCs (30). As MDSCs populations can be sorted by presence of Gr1 marker alone and are known to possess suppressive activity on day 5 (31), BMDCs $\mathrm{Gr} 1^{+}$cells were sorted using anti-APC microbeads (Miltenyi, Bergisch Gladbach, Germany) and antiGr1-APC antibody (BD Biosciences, San Jose, CA, USA). The purity of the sorted cell fraction was $>90 \%$.

\section{SPLENOCYTE CO-CULTURE FOR NITRIC OXIDE AND ARGINASE ACTIVITY ASSAYS}

Spleens were harvested from 6- to 8-week-old C57BL/6 mice under sterile conditions. Red blood cells were lysed $(1 \times \mathrm{RBC}$ lysing buffer) and single-cell suspensions were prepared. $\mathrm{Gr}^{+}{ }^{+}$cells isolated from $\mathrm{BM}$ cultures were added to $2 \times 10^{5}$ naïve $\mathrm{C} 57 \mathrm{BL} / 6$ splenocytes per well in 96-well flat bottom plates at $1: 1,1: 2$, and $1: 4$ ratios. These co-cultures were stimulated with $1 \mu \mathrm{g} / \mathrm{ml}$ antiCD3 antibody (BD Biosciences, San Jose, CA, USA). Following a 72-h incubation, supernatants and cell lysates were collected. The supernatants were assessed for NO production and the cell lysates were used to determine arginase activity. $\mathrm{Gr}^{+}{ }^{+}$cells from BM cultures of tumor-bearing mice were incubated with freshly isolated splenocytes at the optimal ratio of $1: 1$ for the NO and urea activity assays. Anti-CD3 antibody was added to stimulate splenocytes as MDSCs are activated and produce $\mathrm{NO}$ and urea only in the presence of activated/stimulated T-cells.

\section{NITRIC OXIDE PRODUCTION}

Equal volumes of culture supernatants were mixed with Griess reagent ( $1 \%$ sulfanilamide in $5 \%$ phosphoric acid and $0.1 \% \mathrm{~N}$ 1-naphthylethylenediamine dihydrochloride in double-distilled water; Promega, Fitchburg, WI, USA) and incubated at room temperature for $10 \mathrm{~min}$. The absorbance was measured at $550 \mathrm{~nm}$ using a BioTek microplate reader (BioTek, Winooski, VT, USA). Nitrate concentrations $(\mu \mathrm{M})$ were determined by comparing sample OD values to a standard curve generated by serial dilution of $0.1 \mathrm{mM}$ sodium nitrite.

\section{ARGINASE ACTIVITY}

$\mathrm{Gr}^{+}$cells were lysed for $30 \mathrm{~min}$ with $100 \mu \mathrm{l}$ of $0.1 \%$ Triton $\mathrm{X}-100$. Subsequently, $100 \mu \mathrm{l}$ of $25 \mathrm{mM}$ Tris- $\mathrm{HCl}$ and $10 \mu \mathrm{l}$ of $10 \mathrm{mM} \mathrm{MnCl}_{2}$ were added. The arginase enzyme was activated by heating the lysate for $10 \mathrm{~min}$ at $56^{\circ} \mathrm{C} .100 \mu \mathrm{l}$ of $0.5 \mathrm{M} \mathrm{L}$ arginine ( $\mathrm{pH} 9.7$ ) substrate was added to the lysate and incubated for $120 \mathrm{~min}$ at $37^{\circ} \mathrm{C}$. Reaction was stopped with $900 \mu \mathrm{l}$ of acid mixture $1 \mathrm{H}_{2} \mathrm{SO}_{4}$ (96\%): $3 \mathrm{H}_{3} \mathrm{PO}_{4}(85 \%): 7 \mathrm{H}_{2} \mathrm{O}$. $40 \mu \mathrm{l}$ of $\alpha-$ isonitrosopropiophenone (dissolved in $100 \%$ ethanol) was added to the mixture and heated for $30 \mathrm{~min}$ at $95^{\circ} \mathrm{C}$. Absorbance was measured at $540 \mathrm{~nm}$. The urea concentrations $(\mu \mathrm{M})$ were determined by comparing sample OD values to urea standards generated by serial dilution of $1 \mathrm{mM}$ urea solution.

\section{LYMPHOCYTE PROLIFERATION ASSAY}

To monitor lymphocyte proliferation in the presence of $\mathrm{Gr}^{+}$ MDSCs, single-cell suspensions of splenocytes harvested from 6to 8-week-old C57BL/6 mice were stained using the CellTrace CFSE Cell Proliferation Kit (Molecular Probes, Eugene, OR, USA). The splenocytes were centrifuged at $2000 \mathrm{rpm}$ for $2 \mathrm{~min}$ to obtain a pellet. The pellet was re-suspended in pre-warmed PBS with $0.1 \%$ BSA containing the probe at a final working concentration of $10 \mu \mathrm{M}$ to a final concentration of $1 \times 10^{6}$ cells $/ \mathrm{ml}$. Cells were incubated at $37^{\circ} \mathrm{C}$ for $15 \mathrm{~min}$, and then pelleted by centrifugation at $2000 \mathrm{rpm}$ for $2 \mathrm{~min}$. Labeled cells were re-suspended in pre-warmed media, and incubated for $30 \mathrm{~min}$ at $37^{\circ} \mathrm{C}$. The cells were then pelleted again by centrifugation and washed twice before being re-suspended in media supplemented with serum at the desired concentration. To measure the fluorescence at Day $0,0.5 \times 10^{6}$ cells were kept aside. After 3 days the fluorescence was determined. CFSE dilution was analyzed using FACSCalibur and further analyzed with the FlowJo software. Data was expressed in terms of a proliferation index wherein MFI values of CSFE fluorescence are normalized to Day 0 CFSE fluorescence of splenocytes.

\section{WESTERN BLOTS AND ELISA}

Protein lysates ( $30 \mu \mathrm{g}$ per sample) were separated by SDS-PAGE and transferred to PVDF membrane for immunoblotting. AntiCOX-2, anti-MUC1 TR (extracellular portion of MUC1), antiMUC1 CT (cytoplasmic tail of MUC1), and anti-IL-10 antibodies (SantaCruz Biotechnology, Dallas, TX, USA) were used.

$\mathrm{PGE}_{2}$ ELISAs were performed using the Prostaglandin $\mathrm{E}_{2}$ EIA Kit-Monoclonal kit (Cayman Chemical; Ann Arbor, MI, USA) on 
TCCM and FCM. PGEM (13,14-dihydro 15-keto PGA 2$)$ ELISAs were performed using the Prostaglandin E Metabolite EIA Kit (Cayman Chemical; Ann Arbor, MI, USA) on tumor lysates and serum from tumor-bearing mice. $\mathrm{PGE}_{2}$ is metabolized rapidly in vivo and hence an accurate measurement of $\mathrm{PGE}_{2}$ is not possible from in vivo samples, therefore the $\mathrm{PGE}_{2}$ metabolite (PGEM) concentration is assessed in the serum and tumor lysate of tumor-bearing mice.

\section{PROTEOMICS}

$\mathrm{KCM}$ and $\mathrm{KCKO}$-tumor lysates from tumor-bearing mice were electrophoretically separated, gel slices digested with trypsin and analyzed using a Nano Acuity UPLC system connected to an LTQOrbitrap hybrid MS system with a Nanospray interface. Data were collected using Xcaliber and processed using Bioworks software and mouse v.3.18 FASTA database. The following SEQUEST parameters were used: mass tolerance of $0.01 \mathrm{Da}$ for precursor ions and 0.5 Da for fragment ions, variable modification on methionine of $16 \mathrm{Da}$, and maximum missed cleavage of 1 . Search results were entered into Scaffold software (Proteome Software; Portland, OR, USA) for compilation, normalization, and comparison of spectral counts. Protein identifications were made at the peptide probability of $95 \%$ and protein probability of $99 \%$. Experiments for Mass spectroscopy were duplicated for a power law global error model (PLGEM). Datasets were imported into the R program for statistical computing. Data are displayed as fold increase in KCM cells/tumors as compared to KCKO cells/tumors.

\section{STATISTICAL ANALYSES}

All data are expressed as mean \pm SEM. Differences between conditions tested were determined by one-way ANOVA followed by Tukey's post hoc test using GraphPad Prism 5.0 software (La Jolla, CA, USA). The functional assays were analyzed by twoway ANOVA followed by Bonferroni post-test using GraphPad Prism 5.0 software. Probability values of $p \leq 0.05$ were considered significant.

\section{RESULTS}

\section{TDSFS FROM MUC1 EXPRESSING PDA CELLS FAVOR THE EXPANSION OF MONOCYTIC MDSCS}

Bone marrow cells were cultured in media supplemented with GM-CSF and IL-4 with or without 30\% v/v TCCM from KCM or KCKO to determine whether MUC1 expression in PDA cells affects MDSC expansion from BM cells. MUC1 expression was determined by western blotting using two antibodies, one to the MUC1 extracellular tandem repeat domain (MUC1 TR, $>250 \mathrm{kDa}$ ) and one to the cytoplasmic tail domain (MUC1 CT, $<30 \mathrm{kDA}$ ). KCM cells express high levels of MUC1 while KCKO, B16 (positive control), and 3T12 (negative control) cells do not (Figure 1A). On day 5 of BM culture, $\mathrm{Gr}^{+}{ }^{+} \mathrm{CD} 11 \mathrm{~b}^{+}$cells were analyzed by flow cytometry. With no TCCM (none) and FCM from 3T12 cells, $30 \%$ of the BM cells were $\mathrm{Gr}^{+}{ }^{+} \mathrm{CD} 11 \mathrm{~b}^{+}$(Figure 1B) confirming previous observations (24). BM cells cultured with B16 TCCM generated $>40 \% \mathrm{Gr}^{+} \mathrm{CD} 1 \mathrm{~b}^{+}$cells also corroborating previous reports (24). BM cells cultured with KCM TCCM and KCKO TCCM also generated $\sim 40 \% \mathrm{Gr}^{+} \mathrm{CD} 11 \mathrm{~b}^{+}$cells. However, no difference was noted in the $\mathrm{Grl}^{+} \mathrm{CD} 11 \mathrm{~b}^{+}$population between $\mathrm{KCM}$ and $\mathrm{KCKO}$ TCCM (Figure 1B).
Next, we examined whether the presence of MUC1 in PDA cells influences the differential expansion of the MDSC subsets, i.e., monocytic versus granulocytic $(24,32)$. Cells were gated on $\mathrm{CD}_{11} \mathrm{~b}^{+}$population and the two subset populations were analyzed based on presence/absence of Ly6G. A significant increase in the monocytic subset $\left(\mathrm{CD} 11 \mathrm{~b}^{+} \mathrm{Ly}_{6 \mathrm{G}}{ }^{-} \mathrm{Ly}_{6 \mathrm{C}}{ }^{+}, \sim 50\right.$ versus $35 \%$, $p<0.05)$ and a corresponding decrease in the granulocytic subset $\left(\mathrm{CD} 11 \mathrm{~b}^{+} \mathrm{Ly}_{6 \mathrm{G}}{ }^{+} \mathrm{Ly}_{6 \mathrm{C}}^{+}\right.$, 35 vs. $~ 45 \%, p<0.01$ ) was observed in the BM cells treated with TCCM from KCM cells compared to TCCM from KCKO cells (Figure 1C). Significantly, fewer monocytic MDSCs were induced when BM cells were cultured with $3 \mathrm{~T} 12$ FCM compared to TCCM from B16 or KCM cells (Figure 1C).

\section{EXPRESSION OF MUC1 BY PDA CELLS HINDERS MDSC MATURATION}

It is known that less mature MDSCs are more suppressive than mature MDSCs $(24,33)$. Thus, we assessed the maturation state of the MDSCs. An array of maturation and activation markers including CD11c, CD115, CD80, CD86, F4/80, CD40, MHC class I, MHC class II, B7H-1, and B7H-4 were analyzed. There was no change in CD80, CD86, F4/80, CD40, MHC class I or II, B7H-1, and $\mathrm{B} 7 \mathrm{H}-4$ levels (data not shown). However, we did observe a significant upregulation in CD11c expression on the $\mathrm{CD} 11 \mathrm{~b}^{+}$population when BM cells were cultured in the presence of TCCM from KCKO cells (Figure 2A) but not from KCM cells. CD11c (integrin alpha X chain) is one of the markers of MDSC maturation and is used to describe a subpopulation of mature MDSCs (34). Second, we noted a significant down-regulation of CD115 expression on the $\mathrm{CD} 11 \mathrm{~b}^{+}$population when BM cells were cultured with TCCM from KCM cells but not KCKO cells (Figure 2B). CD115 is a receptor for colony-stimulating factor 1 (CSF-1) and is expressed on monocytes, macrophages, and macrophage/dendritic cell precursors and is a marker of mature myeloid cells (35). It is important to note that of all the maturation and activation markers assessed, a notable change was only observed in two markers. These markers are myeloid maturation markers while the others are myeloid activation markers indicating that TCCM from KCKO cells may promote maturation of MDSCs while TCCM from KCM cells hinders its maturation.

\section{EXPRESSION OF MUC1 IN PDA CELLS PROMOTES A SUPPRESSIVE MDSC PHENOTYPE}

We investigated whether the KCM-derived MDSCs were more suppressive than the KCKO-derived MDSCs by evaluating the expressions of iNOS and Arg-1 along with the concentrations of their downstream byproducts, NO and urea, respectively. The intracellular enzymes iNOS and Arg-1 are strongly associated with MDSC-mediated suppression (4) and elevated levels of NO and urea are produced by activated suppressive MDSCs (24). Significant increases in the expression of NOS $^{+}$and Arg- ${ }^{+}$cells were observed within the KCM-derived versus KCKO-derived $\mathrm{Gr}^{+} \mathrm{CD}^{+} 1 \mathrm{~b}^{+} \mathrm{MDSC}$ population (Figures 2C,D). To assess the concentration of $\mathrm{NO}$ and urea, $\mathrm{Gr}^{+}$cells (MDSCs) were sorted from BM cultures treated with TCCM or FCM and co-cultured with varying ratios of activated splenocytes for 3 days. Significantly, higher concentrations of $\mathrm{NO}$ and urea were produced by KCM-derived MDSCs as compared to KCKO-derived MDSCs (Figure 2E). 

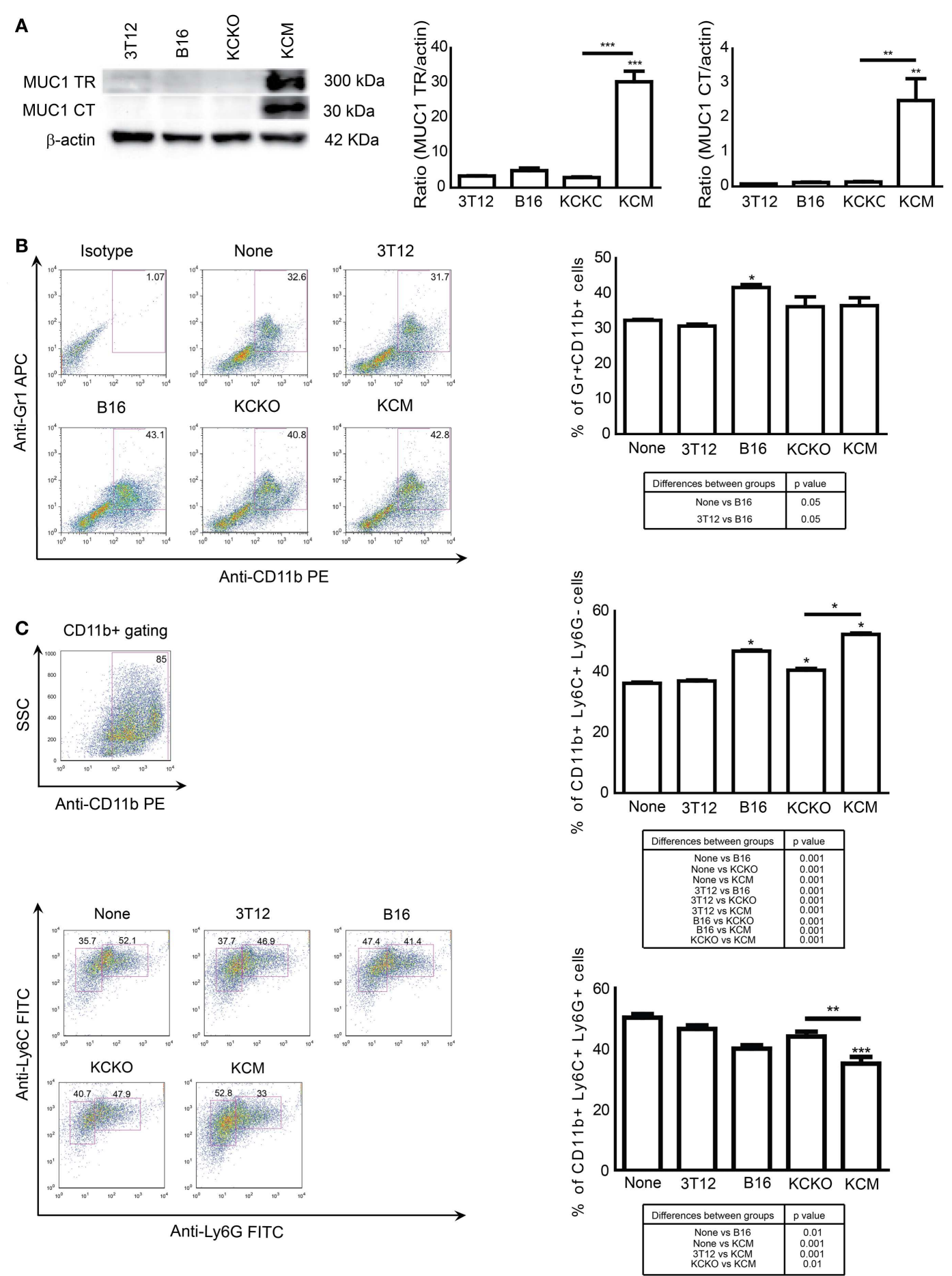

FIGURE 1 | Generation of MDSCs in the presence of various TDSFs

in vitro. BM cells were harvested from 6- to 8-week C57BL/6 mice $(n=4)$, cultured for 5 days with GM-CSF, IL-4, and with or without $30 \% \mathrm{v} / \mathrm{v}$ TCCM/FCM. Cells were stained with anti-Gr1, anti-CD11b, anti-Ly6C, and anti-Ly6G antibodies and analyzed by flow cytometry. (A) Western blot analysis and quantitative densitometry of the protein expressions of MUC1 probed with anti-MUC1 TR (detects extracellular motif of MUC1) and anti-MUC1 CT (detects cytoplasmic tail motif of MUC1) antibodies on cell lysates. MUC1 protein expression normalized to $\beta$-actin protein expression.
Western blotting for MUC1 and $\beta$-actin protein expression was carried out three times; (B) Representative dot plot and graph of percent $\mathrm{Gr} 1{ }^{+} \mathrm{CD} 11 \mathrm{~b}^{+}$ cells; (C) Representative dot plot and graph of percent CD11 $\mathrm{b}^{+} \mathrm{Ly}_{6 \mathrm{C}^{+} \mathrm{LyG}^{-}}$ and $\mathrm{CD} 11 \mathrm{~b}^{+} \mathrm{Ly}_{6 \mathrm{C}}+\mathrm{Ly}_{6 \mathrm{G}}{ }^{+}$cells. The MDSC subsets were obtained by gating on $\mathrm{CD}_{11} \mathrm{~b}^{+}$cells as indicated (top left plot). Percentages are not absolute numbers. Mean and standard error are plotted. ${ }^{*} p<0.5,{ }^{*} p<0.01$, and ${ }^{* * *} p<0.001$ for statistically significant differences from control (3T12) levels unless indicated by the line above the bars. A table of statistically significant differences between each group is provided below dot plots. 

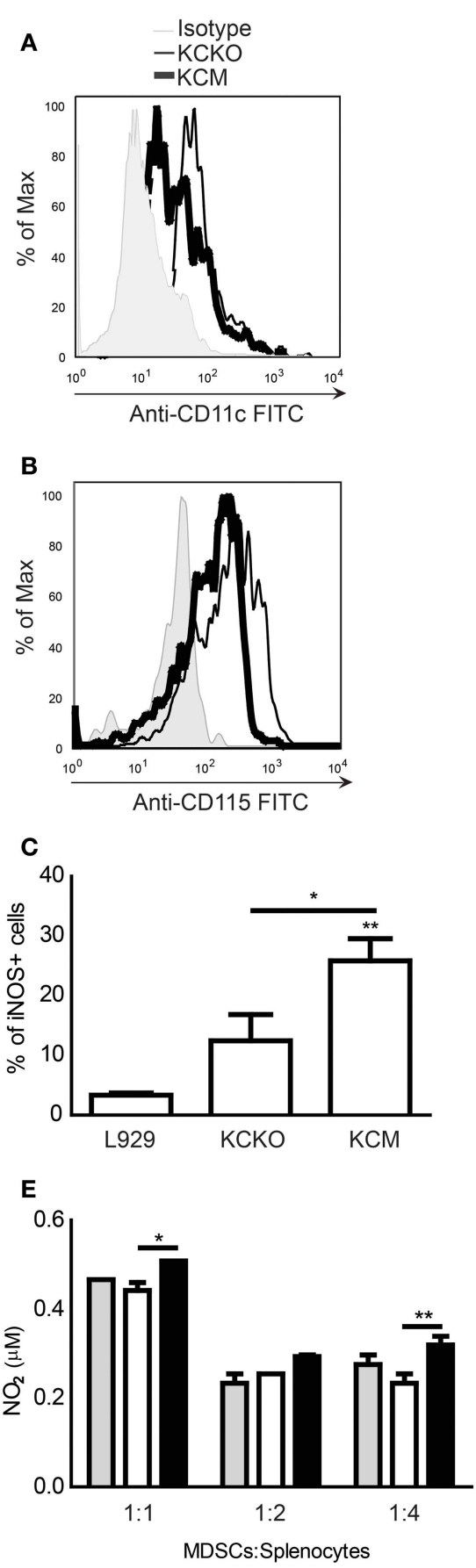

FIGURE 2 | Analysis of maturation and suppression markers on MDSCs in response to various TDSFs in vitro. BM cultures were established as described ( $n=4$ mice). Cells were stained with anti-Gr1, anti-CD11b, anti-CD11C, anti-CD115, anti-iNOS, and anti-Arg-1 antibodies and analyzed by flow cytometry. (A) CD11c expression on $\mathrm{CD}_{11} \mathrm{~b}^{+}$gated cells treated with various TCCM; (B) CD115 expression on CD11 $\mathrm{b}^{+}$gated cells treated with various TCCM. Results are expressed as mean fluorescence intensity (MFI) along with representative histogram. Mean and standard error are plotted. ${ }^{* *} p<0.001$ for statistically significant differences from control (3T12) levels and ${ }^{* *} p<0.01$ for CD115 MFI differences between KCKO TCCM and KCM
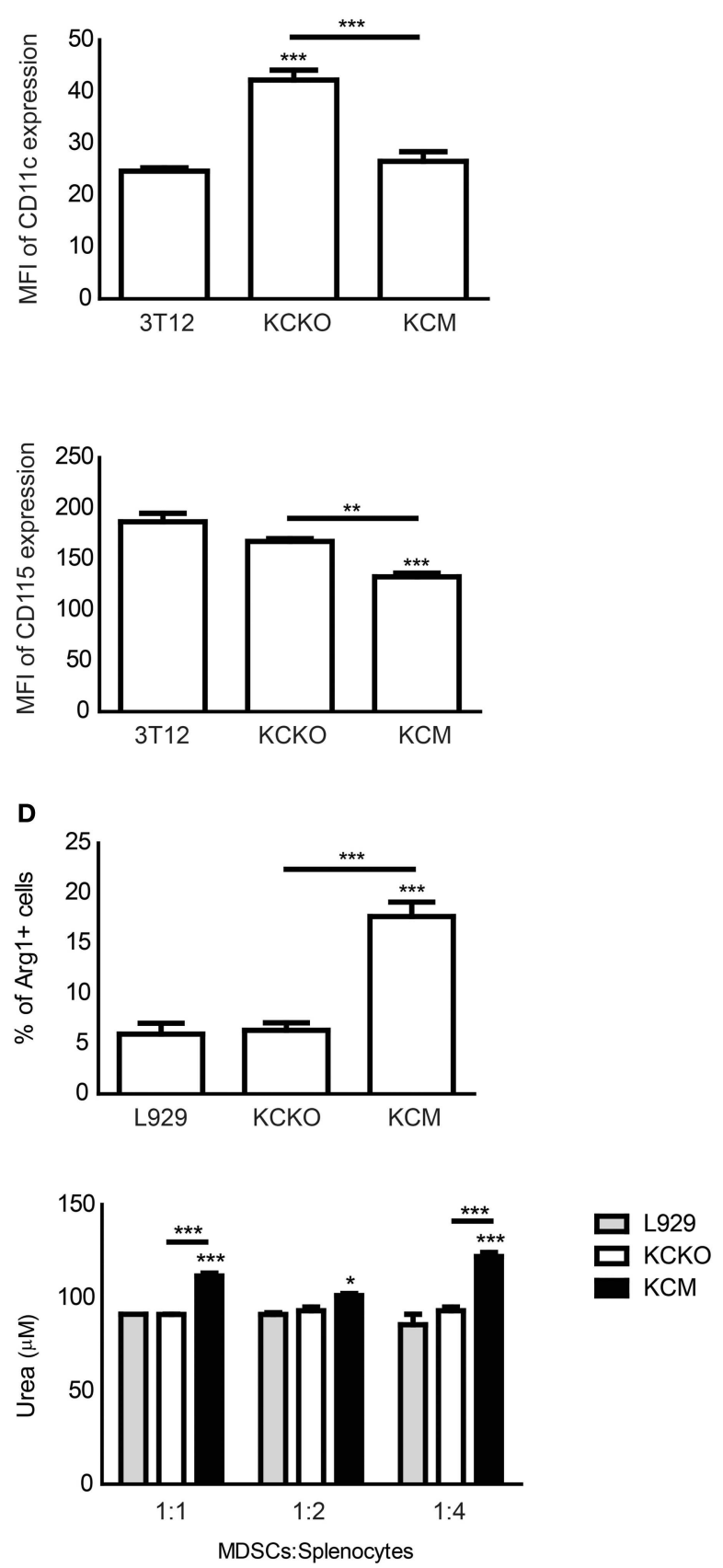

TCCM; (C) Percent of iNOS ${ }^{+}$cells on $\mathrm{Gr}^{+}{ }^{+} \mathrm{CD} 11 \mathrm{~b}^{+}$gated cells treated with various TCCM; (D) Percent of Arg- $1^{+}$cells on $\mathrm{Gr} 1{ }^{+} \mathrm{CD} 11 \mathrm{~b}^{+}$gated cells treated with various TCCM. Percentages are not absolute numbers; (E) $\mathrm{Gr} 1^{+}$cells from BM cultures were co-cultured with freshly isolated splenocytes stimulated with anti-CD3 for 3 days at ratios of $1: 1,1: 2$, and $1: 4$ for $72 \mathrm{~h}$. The nitric oxide concentration was assessed in the co-culture supernatant and the urea concentration was assessed in the cell lysate. One representative experiment out of three is shown. Mean and standard error are plotted. ${ }^{*} p<0.05,{ }^{*} p<0.01$, and ${ }^{*}{ }^{*} p<0.001$ for statistically significant differences from control (L929) levels unless indicated by the line above the bars. 
KCM-TUMOR-BEARING MICE EXHIBIT HIGHER LEVELS OF MDSCS THAT RETAIN THEIR IMMATURE STATE

To recapitulate the in vitro data in an in vivo setting, C57BL/6 mice were injected subcutaneously with 3T12, KCKO, and KCM cells. At time of euthanasia (17 days post tumor challenge), tumors were dissected and weighed. KCM-tumors were significantly larger than the KCKO or 3T12 tumors (Figure 3A), matching previous observations reported by our group (9).

Significantly, higher levels of $\mathrm{Gr}^{+} \mathrm{CD}^{+} 1 \mathrm{~b}^{+}$MDSCs were observed in the spleen of KCM-tumor-bearing mice as compared to KCKO or 3T12-tumor-bearing mice (Figure 3B). Although no change in percent of MDSC was observed in the BM of KCM versus KCKO-tumor-bearing mice (Figure 3C), the numbers of monocytic and granulocytic populations were significantly higher and lower, respectively, in the KCM compared to KCKO and 3T12tumor-bearing mice (Figures 3D,E) corroborating the in vitro data (Figure 1C). Moreover, BM-derived MDSCs from KCM-tumorbearing mice had lower expression of CD11c and CD115 as compared to MDSCs from KCKO-tumor-bearing mice (Figures 3F,G). Thus, data clearly suggests that MDSCs from KCM-tumor-bearing mice retain their immature state in vivo.

\section{MDSCS FROM KCM-TUMOR-BEARING MICE ARE IMMUNOSUPPRESSIVE}

We assessed the expression of iNOS and Arg-1 on the MDSCs from the $\mathrm{BM}$ of tumor-bearing mice. The percent of $\mathrm{Gr}^{+} \mathrm{CD}^{+} 1 \mathrm{~b}^{+}$ MDSCs expressing iNOS and Arg-1 were significantly higher in KCM as compared to KCKO and 3T12-tumor-bearing mice (Figures 4A,B). Further, when BM-derived MDSCs from KCMtumor-bearing mice were co-cultured with varying ratios of activated splenocytes, higher concentrations of $\mathrm{NO}$ and urea were produced (Figures 4C,D) at optimal co-culture ratios of 1:2 for NO and 1:1 for urea. MDSCs from KCKO mice failed to produce NO or urea above basal levels (Figures 4C,D). In addition, data shown in Figure 4E suggests that BM-derived MDSCs from KCM-tumor-bearing mice may be capable of suppressing lymphocyte proliferation in a dose dependant manner to a greater extent than BM-derived MDSCs from KCKO-tumor-bearing mice. For this experiment, MDSCs had to be pooled from $n=3$ mice due to limited numbers of MDSCs obtained after sorting to conduct the co-culture. Therefore, technical replicates were done and $p$-values could not be generated using the two-way ANOVA statistical test. However, a paired $t$-test between KCKO and KCM MFI values was done for equivalent dilutions. The difference was found to be significant $(p \leq 0.05)$ at each dilution. A representative of three experiments is shown in Figure 4E.

\section{KCM CELLS EXPRESS SIGNIFICANTLY HIGHER LEVELS OF IL-10, COX-1, AND 2, PGE SYNTHASE 2 AND 3, AND RELEASE HIGHER LEVELS OF PGE THAN KCKO CELLS}

To determine the mechanism(s) underlying the MUC1 driven generation of suppressive MDSCs, we assessed various immunosuppressive factors (TDSFs) implicated in MDSC generation. We detected significantly higher levels of COX-2 and IL- 10 by western blotting in KCM as compared to KCKO and L929 cell lysates (Figure 5A). In Figure 5B, we confirm the presence and absence of MUC1 by flow cytometry in KCM and KCKO from which lysates were made and mice were injected with. In addition, the proteomics data revealed significant fold increases in COX-1 (fourfold), PGE synthase 2 (sevenfold), and PGE synthase-3 (threefold) in $\mathrm{KCM}$ versus KCKO-tumors (Figure $\mathbf{5 C}$ ). These enzymes are involved in prostaglandin metabolism and are known to influence MDSC generation, recruitment, and function in cancer.

Further, the concentration of $\mathrm{PGE}_{2}$, the major byproduct of the COX enzyme activities was significantly higher in the KCM TCCM compared to the KCKO and 3T12 TCCM (Figure 5D). Similarly, levels of PGE metabolite (PGEM; 13,14-dihydro-15-keto $\mathrm{PGA}_{2}$ ) were significantly higher in the tumors and serum of mice bearing the KCM-tumor compared to KCKO and 3T12 tumors (Figures 5E,F).

\section{INHIBITION OF COX-2 REVERSES MUC1 DRIVEN EFFECTS ON MDSC MATURATION AND FUNCTION}

To determine if indeed MUC1 driven effects on MDSC maturation and suppression were mediated by $\mathrm{COX} / \mathrm{PGE}_{2}$, we treated KCM cells with the selective inhibitor of COX-2 (Celecoxib). KCM cells were treated with $50 \mu \mathrm{M}$ of Celecoxib for $48 \mathrm{~h}$ and TCCM collected. Treatment with Celecoxib significantly reduced the expression of COX-2 in KCM cells as determined by western blot analyses (Figure 6A). When BM cells were cultured with TCCM from KCKO, KCM, and Celecoxibtreated KCM cells, we observed no differences in the numbers of total $\mathrm{Gr} 1^{+} \mathrm{CD} 11 \mathrm{~b}^{+}$cells (Figure 6B). However, a significant increase was observed in the expression of the maturation markers (CD11c and CD115) in MDSCs derived using TCCM from Celecoxib-treated KCM cells (Figures 6C,D). In addition, a significant decrease in the percentages of iNOS $^{+}$and Arg- ${ }^{+}$cells was observed in MDSCs derived with TCCM from Celecoxib-treated KCM cells, approaching the levels observed with KCKO TCCM (Figures 6E,F). These findings strongly indicate that inhibiting the COX-2 pathway enables the immature KCM-induced MDSCs to undergo maturation and in turn lose their suppressive phenotype.

\section{DISCUSSION}

Patients with pancreatic cancer display high levels of circulating tumor MUC1 (CA19-9) that correlate with poor prognosis and disease recurrence (36). In addition, these patients exhibit significant immune dysfunction characterized by increased levels of immune suppressor cells including $\mathrm{T}_{\text {regs }}$ and MDSCs (37, 38). Although, tumor-associated MUC1 has been reported to be immunosuppressive $(39,40)$, its role in MDSC generation and function in pancreatic cancer has never been explored. We recently reported that tumors from PDA mice that over express human MUC1 have elevated levels of MDSCs and favor a highly immune suppressive and pro-inflammatory microenvironment (13).

In this study, we report that there was a significant increase in total MDSC numbers in the spleen of KCM versus KCKOtumor-bearing mice but no difference in the BM (Figure 3). This implies that KCM-tumor may have a profound effect on the recruitment of MDSCs to the lymphoid organs but not on its differentiation in the BM. Further, we show in vitro that TCCM from KCM cells promote the expansion of a monocytic MDSC subset, that are immature and more suppressive than MDSCs derived 


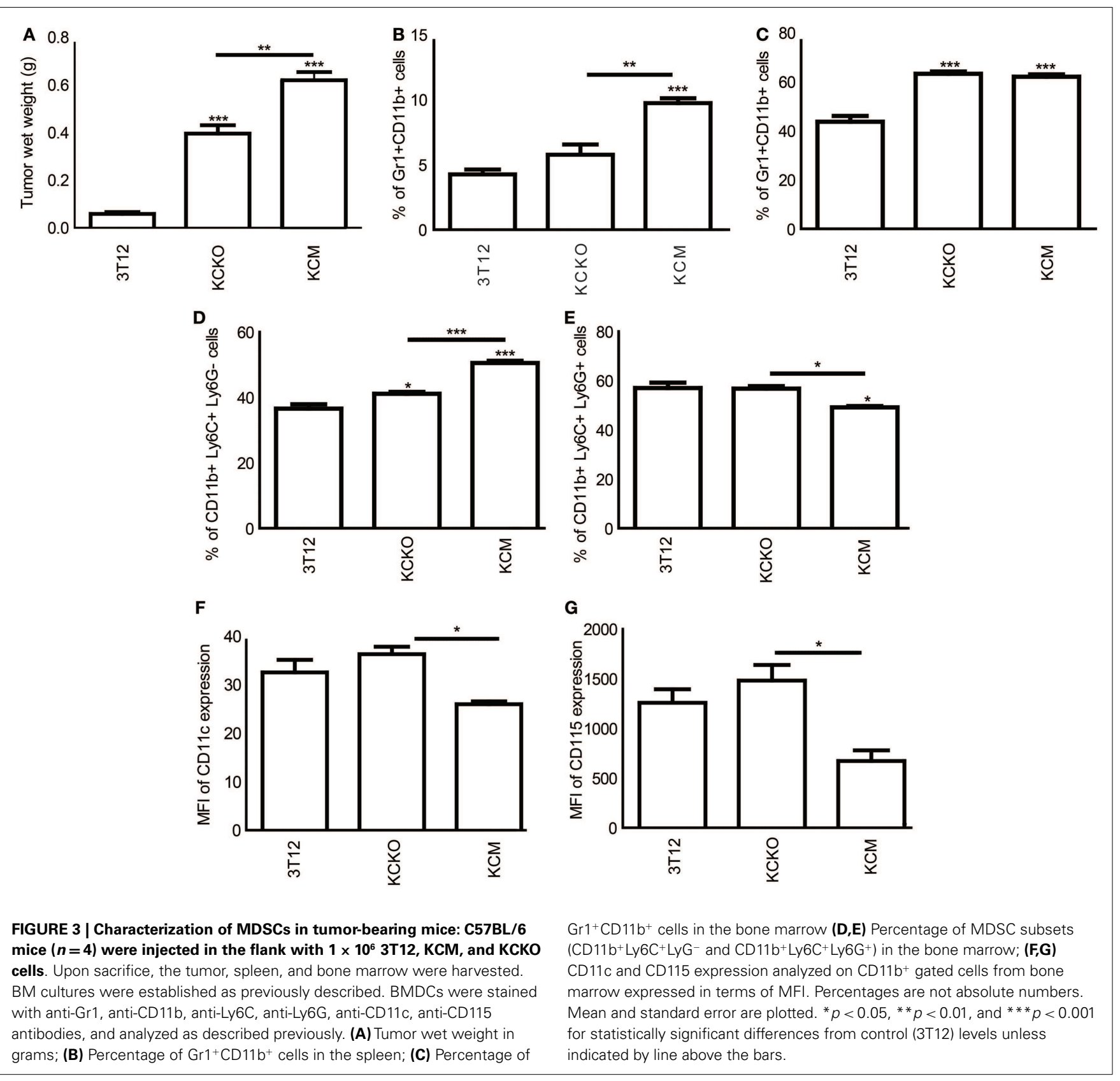

using TCCM from KCKO cells (Figure 1). Interestingly, when the individual MDSC subsets were further analyzed for presence of maturation and suppressive markers, lower levels of CD11c and CD115 was observed in both the monocytic and granulocytic MDSC subsets (Figures S1C-F in Supplementary Material). However, an increase in iNOS $^{+}$cells was predominantly in the monocytic subset while an increase in Arg- ${ }^{+}$cells was predominantly in the granulocytic subset (Figures S1G-J in Supplementary Material). The observations that the suppressive activity of MDSCs is primarily conferred by the monocytic subset and that as MDSCs mature, they lose their suppressive capability is supported by several other published studies $(24,32,33)$. Our findings indicate that MUC1 expression in the tumor plays a key role in maintaining the MDSCs in an immature and highly suppressive state and may partially account for the metastatic nature of $\mathrm{MUC1}^{+}$PDA tumors. Indeed, KCM-tumors grow significantly larger than KCKO-tumors in immune competent syngeneic mice $(9,13)$ (Figure 3A).

Both COX-2 and IL-10 are implicated in MDSC expansion and activation (15). It is well established that there is a positive feedback between $\mathrm{PGE}_{2}$ and COX-2 that redirects the differentiation of human dendritic cells toward stable MDSCs $(41,42)$. In line with that, our data demonstrates that KCM cells express high levels of COX-2 and IL-10 (Figure 5A) and stimulates the generation of highly suppressive and immature MDSCs, thus highlighting the clinical significance of the study. Furthermore, compared 

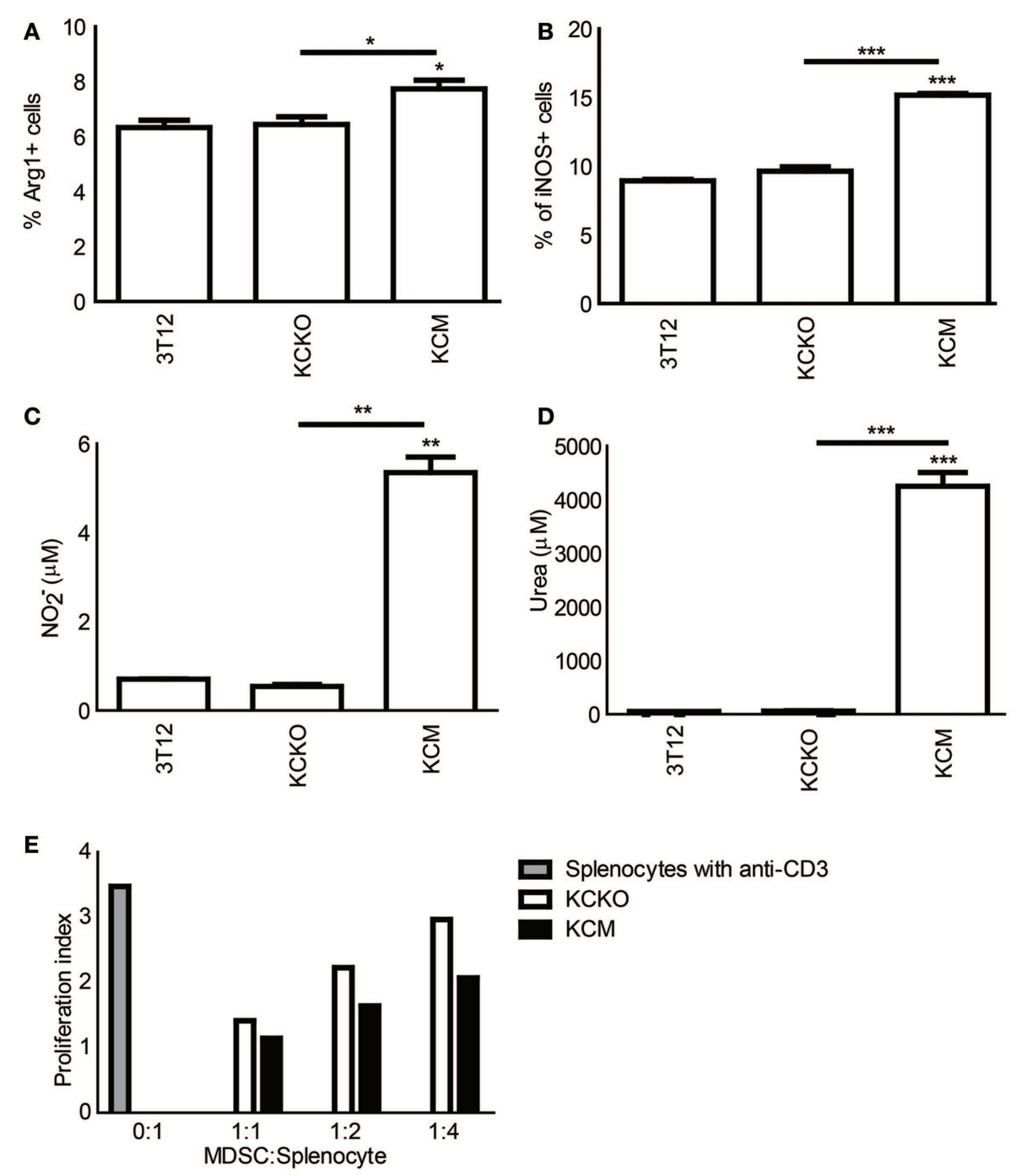

FIGURE 4 | Analysis of suppressive markers on MDSCs in tumor-bearing mice: C57BL/6 mice $(n=4)$ were injected in the flank with $1 \times 10^{6} 3 \mathrm{T12}, \mathrm{KCM}$, and KCKO cells. BM cultures were established as previously described. BMDCs were stained with anti-CD11b, anti-iNOS, and anti-Arg-1 antibodies and analyzed as described previously. (A,B) Percentages iNOS ${ }^{+}$and $\mathrm{Arg}_{-1}{ }^{+}$cells on $\mathrm{Gr} 1^{+} \mathrm{CD} 11 \mathrm{~b}^{+} \mathrm{BM}$ gated cells. Percentages are not absolute numbers; Splenocytes were isolated from naïve $\mathrm{C} 57 \mathrm{BL} / 6$ mice and co-cultured at $1: 1$ ratio with $\mathrm{Gr}{ }^{+}{ }^{+}$cells isolated from $\mathrm{BM}$ cultures from tumor-bearing mice for $\mathrm{NO}$ and urea production analyses. (C,D) Concentrations of $\mathrm{NO}$ and urea were assessed in the supernant and cell lysate respectively of freshly isolated splenocytes stimulated for 3 days with anti-CD3 in the presence or absence of sorted $\mathrm{Gr}^{+}$cells from BM cultures of tumor-bearing mice. Mean and standard

to $\mathrm{KCKO}, \mathrm{KCM}$-tumors exhibit a fourfold increase in COX-1, sevenfold increase in PGE synthase-2, and threefold increase in PGE synthase-3 levels (Figure 5C). Thus, we postulate that KCM cells may activate the COX-pathway which in turn contributes to the generation of suppressive MDSCs. These increases in the COX-pathway enzymes were correlated with elevated levels of $\mathrm{PGE}_{2}$ in the TCCM from KCM-tumor cells and PGEM (PGE metabolite) in the tumor and serum of KCM-tumor-bearing mice

error are plotted. For $(\mathbf{A}, \mathbf{B}){ }^{*} p<0.05,{ }^{*} p<0.01$, and ${ }^{* * *} p<0.001$ for statistically significant differences from control (3T12) levels unless indicated by line above the bars; (E) CFSE labeled splenic cells were stimulated for 3 days with anti-CD3 in the presence or absence of sorted $\mathrm{Gr} 1^{+}$cells at varying ratios from BM cultures of tumor-bearing mice to assess lymphocyte proliferation. Data is expressed in terms of proliferation index (all CSFE MFI were normalized to Day O CFSE fluorescence of splenocytes). Data is representative of one of three experiments. Due to technical issues, there were no biological replicates for this experiment and hence a two-way ANOVA could not be performed. However, a paired t-test was conducted between KCKO and KCM MFI values for equivalent dilutions. The difference was found to be significant $(p \leq 0.05)$ at each dilution (not shown).

(Figures 5D-F). Thus, when TCCM from celecoxib-treated KCM cells was used, the MDSCs generated expressed low suppressive factors and high maturation markers similar to the phenotype generated with KCKO TCCM (Figures 6C-F). The PGE synthases along with COX-1 and COX-2 are essential for the synthesis of prostaglandins including $\mathrm{PGE}_{2}$ from Prostaglandin $\mathrm{H}_{2}$ and are being explored as novel therapeutic targets for treatment of various inflammatory diseases and cancer $(43,44)$. The central role 

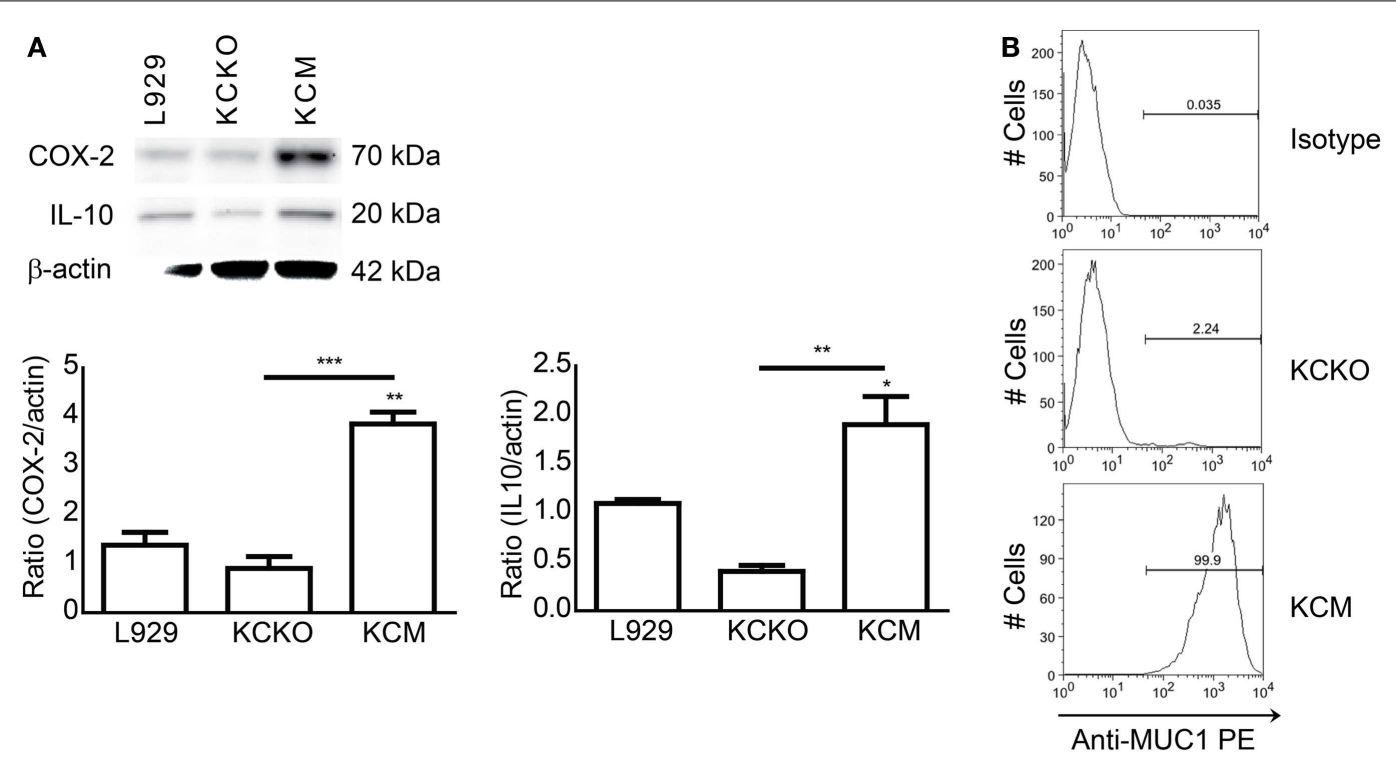

C

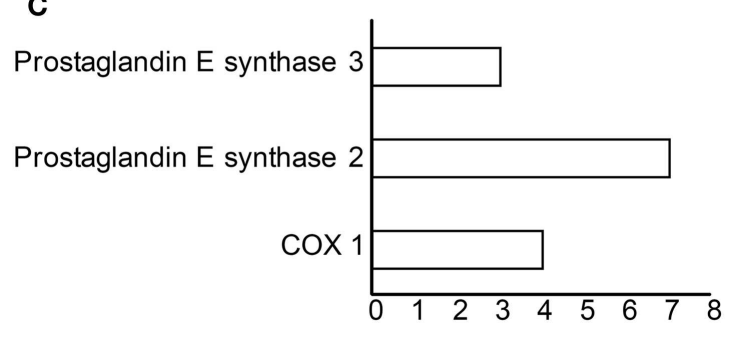

Fold increase in KCM vs. KCKO

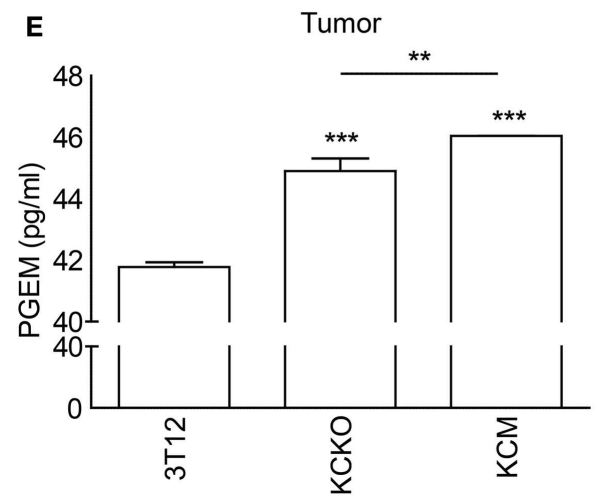

FIGURE 5 | Analysis of TDSFs from KCM and KCKO cells involved in MDSC-mediated suppression. Whole cell lysate, conditioned media, tumor lysate, and serum were analyzed for common immune modulating factors. (A) Whole cell lysates $(30 \mu \mathrm{g})$ of KCM and KCKO cells were loaded onto SDS gels and blotted with anti-COX-2, anti-IL-10, and anti- $\beta$-actin. The quantitative densitometry of the protein expressions of COX-2 and IL-10 normalized to $\beta$-actin is shown as well. Western blotting for COX-2, IL-10, and $\beta$-actin protein expression was carried out three times; (B) MUC1 expression in KCKO and $\mathrm{KCM}$ cells determined by flow cytometry. The gate for percentage positive
D
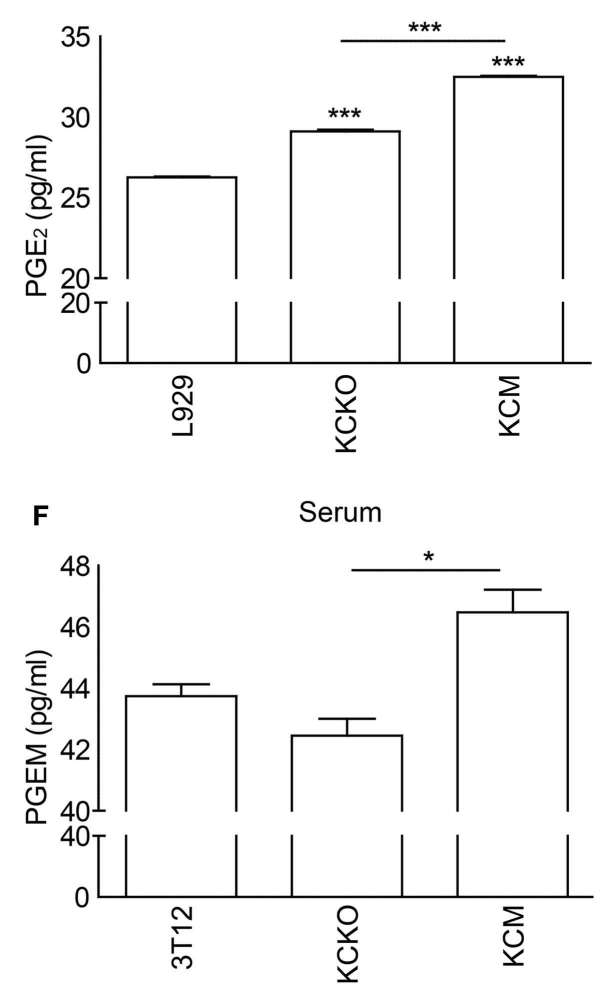

MUC1 cells was set using the appropriate isotype control; (C) Proteins over-expressed in KCM versus KCKO-tumor cell lysates from tumor-bearing mice determined by proteomics analyses (Data expressed in fold changes); (D) $\mathrm{PGE}_{2}$ concentrations in conditioned media of $\mathrm{KCM}$ and $\mathrm{KCKO}$ cells measured by ELISA; (E,F) PGEM (13,14-dihydro-15-keto PGA P $_{2}$ concentrations quantified by ELISA in serum and tumor lysate from tumor-bearing mice $(n=4)$. Mean and standard error plotted. ${ }^{*} p<0.05,{ }^{* *} p<0.01$, and ${ }^{* * *} p<0.001$ for statistically significant differences from control levels unless indicated by the line above the bars. 
A
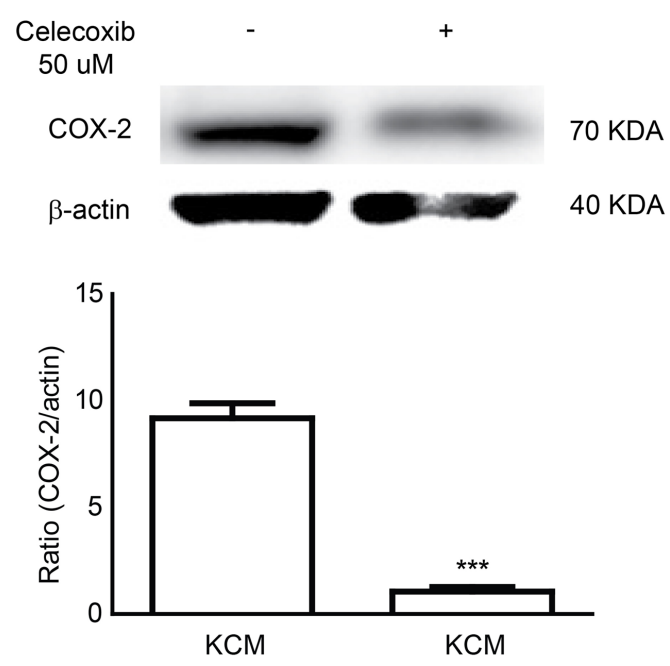

C

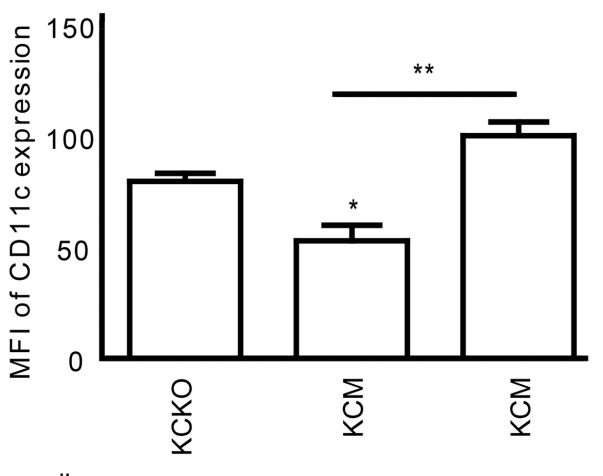

Celecoxib

E

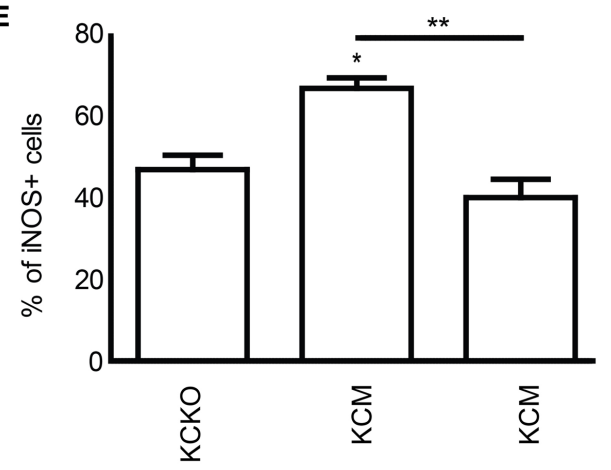

Celecoxib

FIGURE 6 | COX-2 inhibitor Celecoxib reverses the suppressive phenotype of MDSCs. BM cells $(n=4)$ were cultured with $30 \% \mathrm{v} / \mathrm{v}$ TCCM from KCKO, KCM, and celecoxib-treated KCM cells (with $50 \mu \mathrm{M}$ Celecoxib). Cells were stained with anti-Gr1, anti-CD11b, anti-CD11c, anti-CD115, anti-iNOS, and anti-Arg-1 antibodies. (A) Western blot analysis and quantitative densitometry of the protein expression of COX-2 gene on whole cell lysates from KCM and celecoxib-treated KCM cells. COX-2 protein expression was normalized for $\beta$-actin protein
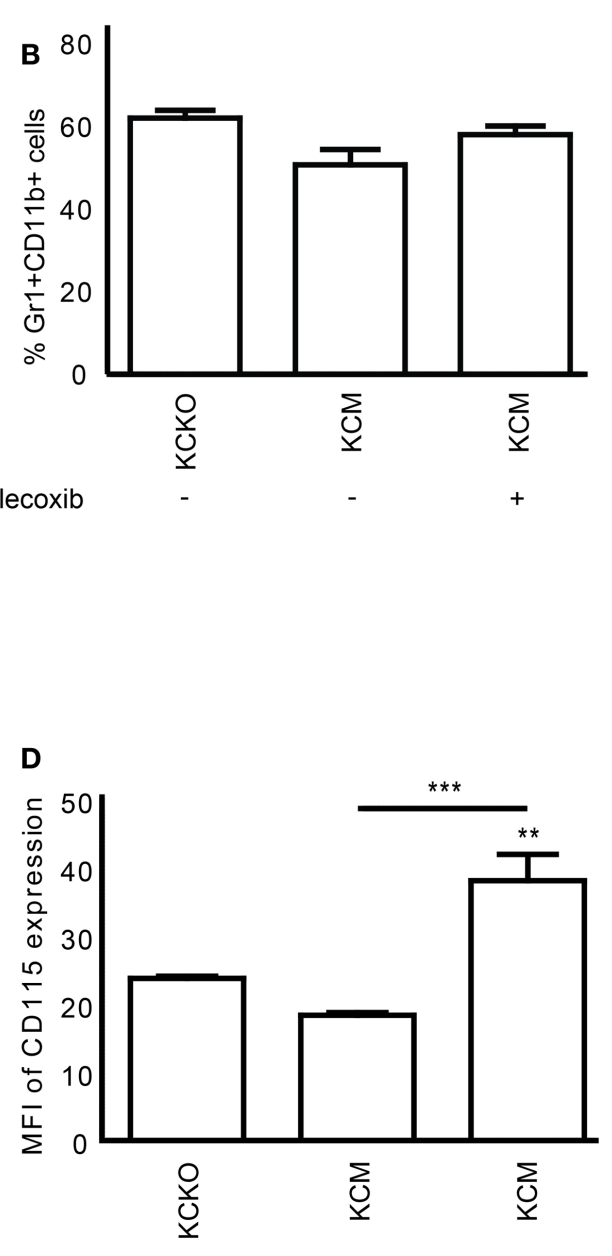

Celecoxib

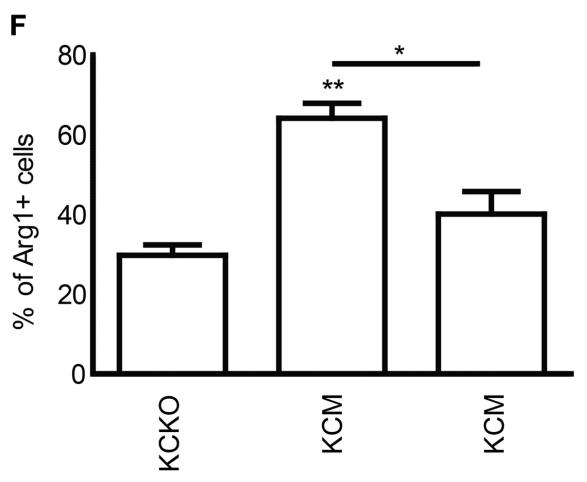

Celecoxib

expression. Western blotting for COX-2 and $\beta$-actin protein expression was carried out 3 times; (B) Percentage of $\mathrm{Gr} 1{ }^{+} \mathrm{CD} 11 \mathrm{~b}+\mathrm{MDSC}$ population; (C,D) Expression of CD11C and CD115 expression on $\mathrm{Gr} 1^{+} \mathrm{CD} 11 \mathrm{~b}^{+}$cells; (E,F) Percentage of $\mathrm{iNOS}^{+}$and Arg- $1^{+}$cells on $\mathrm{Gr} 1{ }^{+} \mathrm{CD} 11 b^{+}$gated cells. Percentages are not absolute numbers. Mean and standard error are shown. ${ }^{*} p<0.05,{ }^{*} p<0.01$, and ${ }^{* *} p<0.001$ for statistically significant differences from KCKO levels unless indicated by the line above the bars. 
of COX-2-PGE 2 feedback in the induction and persistence of MDSCs highlights the potential for its manipulation to enhance or suppress immune responses in cancer $(41,42)$.

Taken together, the data suggests that tumor-associated MUC1 in KCM cells hinders myeloid maturation and drives the generation and maintenance of an immature, suppressive MDSC population partly via activation of the COX-pathway. [Of note is that the two cell lines KCM and KCKO are derived from the same triple transgenic PDA mouse model that expresses the KRAS $S^{G 12 D}$ mutation driven by the P48 promoter and are therefore genetically similar (12) except for the presence or absence of Muc1 $(9,13)]$.

One of the limitations of this study is that all experiments were conducted using KCM and KCKO cell lines. We were unable to conduct these experiments with other cells because there are no other PDA cell lines that are derived in a Muc1-null background. Although there are other low and high MUC1 expressing cells, none that we know lack MUC1 message completely. Since in vivo experiments had to be conducted in immune competent mice, human cell lines could not be used for this study. Nevertheless, to confirm that the effect on MDSC may be regulated by the absence or presence of MUC1, we did conduct some of the same experiments using a melanoma cell line (B16) that completely lacks MUC1 message and protein and is syngeneic for C57/BL6 mice thus avoiding strain-related differences. The B16 cells were stably transfected with full-length human MUC1 (designated B16 MUC1) or empty vector (B16 Neo). Figure S2A in Supplementary Material illustrates high MUC1 expression in B16 MUC1 with undetectable levels in B16 Neo cells. MDSCs were isolated from the BM of B16 MUC1 and B16 Neo-tumor-bearing mice and compared to MDSCs isolated from KCM and KCKO-tumorbearing mice. Results recapitulate the data observed with KCM and KCKO. First, we observed no significant difference in the total numbers of MDSCs between B16 Neo and B16 MUC1 tumorbearing mice. Second, significantly higher numbers of monocytic MDSCs and lower numbers of granulocytic MDSCs was detected in B16 MUC1 versus B16 Neo-tumor-bearing mice (Figures S2BD in Supplementary Material). Finally, compared to MDSCs from B16 Neo-tumor-bearing mice, MDSCs from B16 MUC1 mice expressed significantly higher levels of iNOS (Figures S2E-G in Supplementary Material) and Arg-1 (Figures S2H-J in Supplementary Material). These data confirm that the effect on MDSC maturation and function may be regulated by the absence or presence of MUC1.

The effect of COX-2 inhibition on MDSC function is not surprising as this has been established with other tumor types (45). Our observations indicate that KCM cells express higher levels of COX-2 and secrete higher levels of PGE2 than KCKO cells (Figures 5A,D-F). Thus, we hypothesize that the induction of the highly suppressive and immature MDSCs induced by KCM cells may be via the up regulation of the COX-pathways and synthesis of $\mathrm{PGE}_{2}$. Our upcoming studies will further our understanding of the underlying mechanisms by which the MUC1 glycoprotein regulates the COX-2 pathway in PDA and examine the effects of shed MUC1 on MDSC maturation and function.

In human PDA, MUC1, and COX-2/PGE 2 pathways are highly activated and patients have high levels of MDSCs in the tumor, spleen, and blood, thus our data has high clinical relevance as future therapies can be designed to target MUC1 and COX-2 signaling. Targeting MDSCs along with a cancer antigen greatly improves the efficacy of the cancer vaccine $(46,47)$ and in this regard, we have previously reported that simultaneous targeting of MUC1 and COX-2 in a spontaneous model of PDA was highly effective in stalling the progression of PanIN lesions to adenocarcinomas and in inhibiting invasive disease (48). Data from this study furthers our understanding of the mechanisms by which the combination treatment was effective and provides further rationale for designing clinical trials targeting MUC1 and COX signaling pathways to overcome cancer mediated immune suppression.

Clearly, for the present study to have clinical relevance, these findings have to be validated using patient samples. We have recently published that MUC1 was detected in the circulation of pancreatic cancer patients in a stage-dependent manner (49). Future studies will focus on determining levels of MDSCs and T-regulatory cells in patients with $\mathrm{MUC1}^{+}$and $\mathrm{MUC1}^{-} \mathrm{PDA}$.

\section{AUTHORS CONTRIBUTION}

Amritha Kidiyoor designed all experiments, conducted all experiments, and drafted all versions of the manuscript. Jorge Schettini helped in the design of flow cytometry experiments, helped conduct the first few sets of flow cytometry experiments, helped draft versions of the manuscript and revised manuscript. Dahlia Marie Besmer helped in the design of the in vivo study, helped in injecting tumor cells in mice, and harvesting of bone marrow and spleen, helped conduct experiments on MDSCs collected from tumorbearing mice and edited the manuscript. Stephen Lee Rego helped in the design of the in vivo study and protein work (Westerns and ELISAs), helped in harvesting of bone marrow cells from mice, helped conduct experiments on MDSCs collected from tumorbearing mice, helped conduct Western blot and ELISA experiments and edited the manuscript. Sritama Nath helped conduct experiments on MDSCs collected from tumor-bearing mice, helped conduct a Western blot experiment and edited the manuscript. Jennifer Marie Curry helped in harvesting of organs from tumorbearing mice, helped in setting up flow cytometry experiments, and edited the manuscript. Lopamudra Das Roy helped in harvesting of organs from tumor-bearing mice and edited manuscript. Didier Dreau helped in the design of ELISA experiments and has provided intellectual input throughout preparation of manuscript along with editing and revising manuscript. Pinku Mukherjee, PI of the lab and project, was involved every step of the way in planning of experiments, analyzing results, and preparation of manuscript.

\section{ACKNOWLEDGMENTS}

This work was supported by National Institute of Health Grant RO1 CA118944-01A1 grant (Mukherjee) and the UNCC Belk Endowment Funds (Mukherjee). We thank Dr. Sun-Il Hwang for his contribution toward generating the proteomics data, Dr. Kenneth Bost and Dr. Dan Nelson for their help in designing experiments and the Vivarium staff at University of North Carolina at Charlotte for maintenance of mice colonies.

\section{SUPPLEMENTARY MATERIAL}

The Supplementary Material for this article can be found online at http://www.frontiersin.org/Journal/10.3389/fimmu.2014.00067/ abstract 


\section{REFERENCES}

1. Ferlay J, Shin HR, Bray F, Forman D, Mathers C, Parkin DM. Estimates of worldwide burden of cancer in 2008: GLOBOCAN 2008. Int J Cancer (2010) 127(12):2893-917. doi:10.1002/ijc.25516

2. American Cancer Society. Cancer Facts and Figures 2010. Atlanta: American Cancer Society (2010).

3. Hanahan D, Weinberg RA. Hallmarks of cancer: the next generation. Cell (2011) 144(5):646-74. doi:10.1016/j.cell.2011.02.013

4. Corzo CA, Condamine T, Lu L, Cotter MJ, Youn JI, Cheng P, et al. HIF1 alpha regulates function and differentiation of myeloid-derived suppressor cells in the tumor microenvironment. J Exp Med (2010) 207(11):2439-53. doi:10.1084/jem.20100587

5. Gabrilovich DI, Ostrand-Rosenberg S, Bronte V. Coordinated regulation of myeloid cells by tumours. Nat Rev Immunol (2012) 12(4):253-68. doi:10.1038/ nri3175

6. Rhodes JM. Unifying hypothesis for inflammatory bowel disease and associated colon cancer: sticking the pieces together with sugar. Lancet (1996) 347(8993):40-4. doi:10.1016/S0140-6736(96)91563-9

7. Kufe DW. Mucins in cancer: function, prognosis and therapy. Nat Rev Cancer (2009) 9(12):874-85. doi:10.1038/nrc2761

8. Cheever MA, Allison JP, Ferris AS, Finn OJ, Hastings BM, Hecht TT, et al. The prioritization of cancer antigens: a national cancer institute pilot project for the acceleration of translational research. Clin Cancer Res (2009) 15(17):5323-37. doi:10.1158/1078-0432.CCR-09-0737

9. Besmer DM, Curry JM, Roy LD, Tinder TL, Sahraei M, Schettini J, et al. Pancreatic ductal adenocarcinoma mice lacking mucin 1 have a profound defect in tumor growth and metastasis. Cancer Res (2011) 71(13):4432-42. doi:10.1158/0008-5472.CAN-10-4439

10. Roy LD, Sahraei M, Subramani DB, Besmer D, Nath S, Tinder TL, et al. MUC1 enhances invasiveness of pancreatic cancer cells by inducing epithelial to mesenchymal transition. Oncogene (2011) 30(12):1449-59. doi:10.1038/onc. 2010.526

11. Ren J, Agata N, Chen D, Li Y, Yu WH, Huang L, et al. Human MUC1 carcinomaassociated protein confers resistance to genotoxic anticancer agents. Cancer Cell (2004) 5(2):163-75. doi:10.1016/S1535-6108(04)00020-0

12. Hingorani SR, Petricoin EF, Maitra A, Rajapakse V, King C, Jacobetz MA, et al. Preinvasive and invasive ductal pancreatic cancer and its early detection in the mouse. Cancer Cell (2003) 4(6):437-50. doi:10.1016/S1535-6108(03)00309-X

13. Tinder TL, Subramani DB, Basu GD, Bradley JM, Schettini J, Million A, et al. MUC1 enhances tumor progression and contributes toward immunosuppression in a mouse model of spontaneous pancreatic adenocarcinoma. J Immunol (2008) 181(5):3116-25.

14. Youn JI, Gabrilovich DI. The biology of myeloid-derived suppressor cells: the blessing and the curse of morphological and functional heterogeneity. Eur J Immunol (2010) 40(11):2969-75. doi:10.1002/eji.201040895

15. Gabrilovich DI, Nagaraj S. Myeloid-derived suppressor cells as regulators of the immune system. Nat Rev Immunol (2009) 9(3):162-74. doi:10.1038/nri2506

16. Nagaraj S, Gabrilovich DI. Myeloid-derived suppressor cells. Adv Exp Med Biol (2007) 601:213-23. doi:10.1007/978-0-387-72005-0_22

17. Ostrand-Rosenberg S, Sinha P. Myeloid-derived suppressor cells: linking inflammation and cancer. J Immunol (2009) 182(8):4499-506. doi:10.4049/jimmunol. 0802740

18. Marigo I, Dolcetti L, Serafini P, Zanovello P, Bronte V. Tumor-induced tolerance and immune suppression by myeloid derived suppressor cells. Immunol Rev (2008) 222:162-79. doi:10.1111/j.1600-065X.2008.00602.x

19. Sinha P, Clements VK, Fulton AM, Ostrand-Rosenberg S. Prostaglandin E2 promotes tumor progression by inducing myeloid-derived suppressor cells. Cancer Res (2007) 67(9):4507-13. doi:10.1158/0008-5472.CAN-06-4174

20. Bronte V, Chappell DB, Apolloni E, Cabrelle A, Wang M, Hwu P, et al. Unopposed production of granulocyte-macrophage colony-stimulating factor by tumors inhibits CD8+ T cell responses by dysregulating antigen-presenting cell maturation. J Immunol (1999) 162(10):5728-37.

21. Huang B, Pan PY, Li Q, Sato AI, Levy DE, Bromberg J, et al. Gr-1+CD115+ immature myeloid suppressor cells mediate the development of tumor-induced T regulatory cells and T-cell anergy in tumor-bearing host. Cancer Res (2006) 66(2):1123-31. doi:10.1158/0008-5472.CAN-05-1299

22. Kusmartsev S, Nefedova Y, Yoder D, Gabrilovich DI. Antigen-specific inhibition of CD8+ T cell response by immature myeloid cells in cancer is mediated by reactive oxygen species. J Immunol (2004) 172(2):989-99.
23. Greten TF, Manns MP, Korangy F. Myeloid derived suppressor cells in human diseases. Int Immunopharmacol (2011) 11(7):802-7. doi:10.1016/j.intimp.2011. 01.003

24. Youn JI, Nagaraj S, Collazo M, Gabrilovich DI. Subsets of myeloid-derived suppressor cells in tumor-bearing mice. J Immunol (2008) 181(8):5791-802.

25. Bronte V, Zanovello P. Regulation of immune responses by L-arginine metabolism. Nat Rev Immunol (2005) 5(8):641-54. doi:10.1038/nri1668

26. Rivoltini L, Carrabba M, Huber V, Castelli C, Novellino L, Dalerba P, et al. Immunity to cancer: attack and escape in T lymphocyte-tumor cell interaction. Immunol Rev (2002) 188:97-113. doi:10.1034/j.1600-065X.2002.18809.x

27. Nagaraj S, Gupta K, Pisarev V, Kinarsky L, Sherman S, Kang L, et al. Altered recognition of antigen is a mechanism of CD8+ T cell tolerance in cancer. Nat Med (2007) 13(7):828-35. doi:10.1038/nm1609

28. Cheng P, Corzo CA, Luetteke N, Yu B, Nagaraj S, Bui MM, et al. Inhibition of dendritic cell differentiation and accumulation of myeloid-derived suppressor cells in cancer is regulated by S100A9 protein. J Exp Med (2008) 205(10):2235-49. doi:10.1084/jem.20080132

29. Poh TW, Bradley JM, Mukherjee P, Gendler SJ. Lack of Muc1-regulated betacatenin stability results in aberrant expansion of CD11b+Gr1+ myeloid-derived suppressor cells from the bone marrow. Cancer Res (2009) 69(8):3554-62. doi:10.1158/0008-5472.CAN-08-3806

30. Greifenberg V, Ribechini E, Rossner S, Lutz MB. Myeloid-derived suppressor cell activation by combined LPS and IFN-gamma treatment impairs DC development. Eur J Immunol (2009) 39(10):2865-76. doi:10.1002/eji.200939486

31. Ribechini E, Leenen PJ, Lutz MB. Gr-1 antibody induces STAT signaling, macrophage marker expression and abrogation of myeloid-derived suppressor cell activity in BM cells. Eur J Immunol (2009) 39(12):3538-51. doi:10.1002/eji. 200939530

32. Movahedi K, Guilliams M, Van den Bossche J, Van den Bergh R, Gysemans $\mathrm{C}$, Beschin A, et al. Identification of discrete tumor-induced myeloid-derived suppressor cell subpopulations with distinct $\mathrm{T}$ cell-suppressive activity. Blood (2008) 111(8):4233-44. doi:10.1182/blood-2007-07-099226

33. Poschke I, Mougiakakos D, Hansson J, Masucci GV, Kiessling R. Immature immunosuppressive CD14+HLA-DR-/low cells in melanoma patients are Stat3hi and overexpress CD80, CD83, and DC-sign. Cancer Res (2010) 70(11):4335-45. doi:10.1158/0008-5472.CAN-09-3767

34. Serafini P, Mgebroff S, Noonan K, Borrello I. Myeloid-derived suppressor cells promote cross-tolerance in B-cell lymphoma by expanding regulatory T cells. Cancer Res (2008) 68(13):5439-49. doi:10.1158/0008-5472.CAN-076621

35. Geissmann F, Manz MG, Jung S, Sieweke MH, Merad M, Ley K. Development of monocytes, macrophages, and dendritic cells. Science (2010) 327(5966):656-61. doi:10.1126/science.1178331

36. Yang HS, Tamayo R, Almonte M, Horten B, DaSilva M, Gangi M, et al. Clinical significance of MUC1, MUC2 and CK17 expression patterns for diagnosis of pancreatobiliary carcinoma. Biotech Histochem (2012) 87(2):126-32. doi:10.3109/10520295.2011.570276

37. Gabitass RF, Annels NE, Stocken DD, Pandha HA, Middleton GW. Elevated myeloid-derived suppressor cells in pancreatic, esophageal and gastric cancer are an independent prognostic factor and are associated with significant elevation of the Th2 cytokine interleukin-13. Cancer Immunol Immunother (2011) 60(10):1419-30. doi:10.1007/s00262-011-1028-0

38. Morse MA, Hall JR, Plate JM. Countering tumor-induced immunosuppression during immunotherapy for pancreatic cancer. Expert Opin Biol Ther (2009) 9(3):331-9. doi:10.1517/14712590802715756

39. Chan AK, Lockhart DC, von Bernstorff W, Spanjaard RA, Joo HG, Eberlein TJ, et al. Soluble MUC1 secreted by human epithelial cancer cells mediates immune suppression by blocking T-cell activation. Int J Cancer (1999) 82(5):721-6. doi:10.1002/(SICI)1097-0215(19990827)82:5<721::AID-IJC16>3.3.CO;2-E

40. Agrawal B, Krantz MJ, Reddish MA, Longenecker BM. Cancer-associated MUC1 mucin inhibits human T-cell proliferation, which is reversible by IL-2. Nat Med (1998) 4(1):43-9. doi:10.1038/nm0198-043

41. Obermajer N, Muthuswamy R, Lesnock J, Edwards RP, Kalinski P. Positive feedback between PGE2 and COX2 redirects the differentiation of human dendritic cells toward stable myeloid-derived suppressor cells. Blood (2011) 118(20):5498-505. doi:10.1182/blood-2011-07-365825

42. Ochoa AC, Zea AH, Hernandez C, Rodriguez PC. Arginase, prostaglandins, and myeloid-derived suppressor cells in renal cell carcinoma. Clin Cancer Res (2007) 13(Pt 2):721s-6s. doi:10.1158/1078-0432.CCR-06-2197 
43. Jegerschold C, Pawelzik SC, Purhonen P, Bhakat P, Gheorghe KR, Gyobu N, et al. Structural basis for induced formation of the inflammatory mediator prostaglandin E2. Proc Natl Acad Sci USA (2008) 105(32):11110-5. doi:10.1073/ pnas.0802894105

44. Samuelsson B, Morgenstern R, Jakobsson PJ. Membrane prostaglandin E synthase-1: a novel therapeutic target. Pharmacol Rev (2007) 59(3):207-24. doi:10.1124/pr.59.3.1

45. Veltman JD, Lambers ME, van Nimwegen M, Hendriks RW, Hoogsteden HC, Aerts JG, et al. COX-2 inhibition improves immunotherapy and is associated with decreased numbers of myeloid-derived suppressor cells in mesothelioma. Celecoxib influences MDSC function. BMC Cancer (2010) 10:464. doi:10.1186/1471-2407-10-464

46. Iclozan C, Antonia S, Chiappori A, Chen DT, Gabrilovich D. Therapeutic regulation of myeloid-derived suppressor cells and immune response to cancer vaccine in patients with extensive stage small cell lung cancer. Cancer Immunol Immunother (2013) 62(5):909-18. doi:10.1007/s00262-013-1396-8

47. Mace TA, Ameen Z, Collins A, Wojcik S, Mair M, Young GS, et al. Pancreatic cancer-associated stellate cells promote differentiation of myeloid-derived suppressor cells in a STAT3-dependent manner. Cancer Res (2013) 73(10):3007-18. doi:10.1158/0008-5472.CAN-12-4601

48. Mukherjee P, Basu GD, Tinder TL, Subramani DB, Bradley JM, Arefayene $\mathrm{M}$, et al. Progression of pancreatic adenocarcinoma is significantly impeded with a combination of vaccine and COX-2 inhibition. J Immunol (2009) 182(1):216-24.
49. Curry JM, Thompson KJ, Rao SG, Besmer DM, Murphy AM, Grdzelishvili VZ, et al. The use of a novel MUC1 antibody to identify cancer stem cells and circulating MUC1 in mice and patients with pancreatic cancer. J Surg Oncol (2013) 107(7):713-22. doi:10.1002/jso.23316

Conflict of Interest Statement: The authors declare that the research was conducted in the absence of any commercial or financial relationships that could be construed as a potential conflict of interest.

Received: 01 December 2013; accepted: 07 February 2014; published online: 24 February 2014.

Citation: Kidiyoor A, Schettini J, Besmer DM, Rego SL, Nath S, Curry JM, Roy LD, Dréau D and Mukherjee P (2014) Pancreatic cancer cells isolated from Muc1-null tumors favor the generation of a mature less suppressive MDSC population. Front. Immunol. 5:67. doi: 10.3389/fimmu.2014.00067

This article was submitted to Tumor Immunity, a section of the journal Frontiers in Immunology.

Copyright (C) 2014 Kidiyoor, Schettini, Besmer, Rego, Nath, Curry, Roy, Dréau and Mukherjee. This is an open-access article distributed under the terms of the Creative Commons Attribution License (CC BY). The use, distribution or reproduction in other forums is permitted, provided the original author(s) or licensor are credited and that the original publication in this journal is cited, in accordance with accepted academic practice. No use, distribution or reproduction is permitted which does not comply with these terms. 